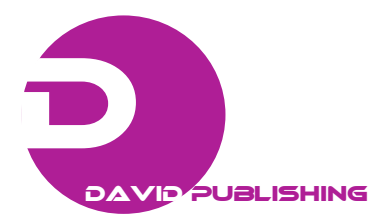

\title{
Establishing Systems for Food Safety and Food Security Based on Integrity
}

\author{
Yuichi Kato \\ QAP \& PS Co. Ltd, 1-31-16 Tsukioka, Sanjou-city, Niigata-Prefecture, Japan \\ Corresponding author's e-mail: y.kato@qaps.co.jp
}

\begin{abstract}
In recent years, food product and service companies have been strictly responsible for corporate social responsibility in Japan because of growing concerns about food safety and food security. Now, some management systems to keep food safety have been developped and introduced. On the other hand, food companies are required to prevent food accidents by taking them adequately and effectively. However, no matter how excellent the system is, it depends on the will of people which engage in food product. Therefore, "integrity" is absolutely requisite. In Japan, many scandals by food disguise have occurred in sequence since 2000. Those scandals brought concern about food safety and security. Many food companies took short views and they forgot the most important mission that they worked for the health and life of many people. Now, many Asian countries are being modern state with rising populations. In addition, developing to highly-networked information society will change the mind of consumer people in your country. Whoever can know and send information. From now on, it is probable that many scandals will be occurred, but if your company is based on integrity and establishes systems for food safety to disclose information about your company, which will be competitive advantage in your market. Next you need the tool for integrity. This is called "7S" and it's an effective method. 7S is an inclusive term, "Seiri, Seiton, Seisou, Senjou, Sakkin, Seiketsu and Sitsuke in Japanese”. It is a basic method to work rightly in the work place of food companies. 5S is well known in general manufacturing business in Japan. Senjou and Sakkin are required for food companies because of prevention control on invisible bacteria. Finally, the visible management system for food security is requisite. All management system is effective on foundation with integrity.
\end{abstract}

Key words: Establishment, food safety system, food security, 7S and integrity. 